AGH DRILLING, OIL, GAS • Vol. $31 \cdot$ No. $1 \cdot 2014$

http://dx.doi.org/10.7494/drill.2014.31.1.167

\author{
Anastasiia Laura*
}

\title{
ANALYSIS OF FRACTURING FLUID SYSTEM, EFFECT OF ROCK MECHANICAL PROPERTIES ON FLUID SELECTION
}

\section{INTRODUCTION}

The fracturing fluid is a main component of the hydraulic fracturing treatment. Opening the fracture and transportation propping agent along the length of the fracture are the principal function of fracturing fluids. Success of hydraulic fracturing treatments depends of the special fluids properties. In addition fluids should break and clean up fracturing the treatment is over, provide good fluid-loss control, exhibit low friction pressure during pumping and be as economical as is practical.

Nowadays many different types of fluids used for fracturing treatments. All reservoirs are varying in terms of geological structure, temperature, permeability and pores pressure that require a special selection of fracturing fluids.

Fracturing fluids can be categorized as oil- or water- based, usually "crosslinked" to provide the necessary viscosity, mixtures of oil and water, called emulsions, and foamed oil- and water- base systems that contain nitrogen or carbon dioxide gas. [1] Water is the one of the common fracturing fluid $-96 \%$ of all fractured wells use it. For example, fracturing treatments for shale gas in the Marcellus basin employ about 1 million gallons of water for vertical wells and 3-6 million gallons for horizontal wells.

Materials and proppant used in hydraulic fracturing have undergone tremendous changes since the first commercial fracturing treatment was performed in 1949 with few sacks of coarse sand and gelled gasoline as the carrier fluid. [1] The first fracturing fluids were oil-base. The earliest fracturing fluids were hydrocarbon-based and utilized "napalm" to obtain the required viscosity. In the 1950s water-base fluids thickened with guar became very popular. By the 1990s more than 90 percent of fracturing fluids were crosslinked water-bases systems. Typically, more than 65 percent of all fracturing treatments use water-base gels viscosified with guar or hydroxypropylguar.

* AGH University of Science and Technology, Faculty of Drilling, Oil and Gas, Krakow, Poland 
[2] Gelled oil treatments and acid fracturing treatments each account for about 5 percent of the total fracturing process. Mostly, the fluids gelled by a polymeric gelling agent. The thickened or gelled fluid helps keep the proppant within the fluid during the fracturing operation. About 20-25 percent of all treatments contain an energizing gas. Additives are used to increase viscosity at high temperatures, to break viscosity at low temperatures or to help control leak off of the fluid to the formation. A wide variety of chemical additives are used in hydraulic fracturing. The chemical composition of the hydraulic fracturing fluids depending conditions of the specific well.

Fracturing fluids must be stable at high temperatures, pumping rates, and shear rates. For fracturing treatments use several types of fracturing fluids and fluid additives.

The types of fluids include:

- Water based fluids

- Oil based fluids

- Energized fluids

- Multi-phase emulsions

- Acid Fluids

The additives include:

- Gelling agents

- Crosslinkers

- Breakers

- Fluid loss additives

- Bactericides

- Surfactants and Non-emulsifying agents

- Clay control Additives.

\section{TYPES OF FRACTURING FLUIDS}

Each fluid has its advantages and disadvantages. In Table 1 provides a listing of the desirable and undesirable aspects of most available fluid systems. A description of all the different components used for hydraulic treatments is provided in Side Bar 1. [4]

Table 1

Qualitative fluid selection chart

\begin{tabular}{|c|c|c|c|c|c|c|c|c|c|c|c|}
\hline \multirow[b]{2}{*}{ Fluid System } & \multirow[b]{2}{*}{ 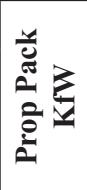 } & \multirow[b]{2}{*}{ 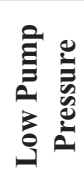 } & \multicolumn{3}{|c|}{ Viscosity } & \multirow[b]{2}{*}{ 最 } & \multicolumn{2}{|c|}{ Compatibility } & \multirow[b]{2}{*}{ 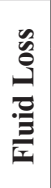 } & \multirow[b]{2}{*}{ 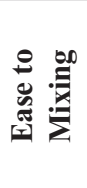 } & \multirow[b]{2}{*}{$\overline{\tilde{\theta}}$} \\
\hline & & & 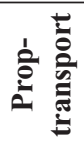 & $\frac{0}{\frac{0}{\pi}}$ & $\stackrel{\mathscr{2}}{3}$ & & 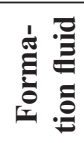 & 을 & & & \\
\hline Water Frac ${ }^{1}$ & 5 & 5 & 1 & 3 & 3 & 5 & 3 & 4 & 1 & 5 & 5 \\
\hline Linear $\mathrm{Gel}^{2}$ & 3 & 5 & 3 & 3 & 3 & 4 & 3 & 4 & 2 & 5 & 4 \\
\hline Linear $\mathrm{Gel}^{3}$ & 5 & 5 & 3 & 3 & 3 & 4 & 3 & 4 & 2 & 5 & 4 \\
\hline Borate X-Link ${ }^{2}$ & 3 & 3 & 5 & 5 & 5 & 3 & 4 & 3 & 5 & 4 & 3 \\
\hline
\end{tabular}


Table 1. cont.

\begin{tabular}{|l|c|c|c|c|c|c|c|c|c|c|c|}
\hline Delayed Borate X-Link $^{2}$ & 3 & 3 & 5 & 5 & 5 & 3 & 4 & 3 & 5 & 3 & 3 \\
\hline Delayed Metalic X-Link $^{4}$ & 3 & 3 & 5 & 2 & 2 & 3 & 4 & 3 & 5 & 3 & 3 \\
\hline Delayed Metalic X-Link & 3 & 3 & 5 & 2 & 2 & 3 & 4 & 3 & 5 & 3 & 3 \\
\hline VES $^{6}$ & 5 & 3 & 5 & 4 & 4 & 2 & 1 & 3 & 2 & 2 & 1 \\
\hline Nitrogen Foam & 5 & 2 & 5 & 3 & 3 & 5 & 4 & 4 & 5 & 2 & 1 \\
\hline $\mathrm{CO}_{2}$ Foams & 5 & 2 & 5 & 3 & 3 & 5 & 4 & 5 & 5 & 2 & 1 \\
\hline Gelled Propane & 5 & 3 & 4 & 4 & 3 & 4 & 5 & 4 & 4 & 2 & 1 \\
\hline Poly Emulsion(K1) & 4 & 1 & 5 & 5 & 5 & 4 & 4 & 3 & 5 & 2 & 3 \\
\hline Lease Grude & 2 & 3 & 2 & 5 & 5 & 5 & 5 & 3 & 2 & 5 & 5 \\
\hline Gelled oil & 2 & 3 & 4 & 4 & 4 & 4 & 3 & 3 & 3 & 4 & 3 \\
\hline
\end{tabular}

Qualitative rate 1 to 5 where 1 is poor, 3 is moderate and 5 is excellent.

1. Uses Polyacrylamide (PAA) as a friction reducer;

2. Uses Guar, HydroxyPropyl Guar or GarboxyMethylHydroxyPropyl Guar (CMHPG) as gelling agent;

3. Uses HydroxyEthyl Cellulose (HEC) or CarboxyMethyhydroxyEthyl Cellulose (CMHEC) as gelling agent;

4. Uses Titanium or Zirconium Crosslinkers for Guar, HPG and CMHPG gelling agents;

5. Uses Titinium or Zirconium Crosslinkers for CMHEC gelling agents;

6. Uses a ViscoElastic Surfactant system as the gelling agent;

7. Uses a Phosphate Ester Crosslinked with an Aluminum Salt and acitivated with a base.

Possible components in a fracturing fluid are listed in Table 2, [2] which indicates the complexity of a fracturing fluid formulation. Some additives can't used together, such as oilgelling additives in a water-based system.

Table 2

Components in Fracturing Fluids

\begin{tabular}{|l|l|}
\hline \multicolumn{1}{|c|}{ Component } & Function/remark \\
\hline Water based polymers & Thickener, to transport proppant, reducer leakoff in formation \\
\hline Friction reducers & Reduce drag in tubing \\
\hline Fluid loss additives & Form filter cake, reduce leakoff in formation if thickener is not sufficient \\
\hline Breakers & $\begin{array}{l}\text { Degrade thickener after job or disable crosslinker (wide variety of chemical } \\
\text { mechanisms) }\end{array}$ \\
\hline Emulsifiers & For diesel premixed gels \\
\hline Clay stabilizers & For clay-bearing formations \\
\hline Surfactants & Prevent water-wetting of formation \\
\hline Nonemulsifiers & Destroy emulsions \\
\hline pH-Control additives & Increase the stability of fluid (e.g., for elevated temperature applications) \\
\hline
\end{tabular}


Table 2. cont.

\begin{tabular}{|l|l|}
\hline \multicolumn{1}{|c|}{ Component } & Function/remark \\
\hline Crosslinkers & Increase the viscosity of the thickener \\
\hline Foamers & For foam-based fracturing fluids \\
\hline Gel stabilizers & Keep gels active longer \\
\hline Defoamers & Break a foam \\
\hline Oil-gelling additives & Same as crosslinkers for oil-based fracturing fluids \\
\hline Biocides & Prevent microbial degradation \\
\hline Water-based systems & Common \\
\hline Crosslinked gel system & Increase viscosity \\
\hline Oil-based systems & Used in water sensitive formation \\
\hline Polymer Plugs & Used also for other operations \\
\hline Gel concentrates & Premixed gel on diesel base \\
\hline Resin-coated proppants & Proppant material \\
\hline Ceramics & Proppant material \\
\hline
\end{tabular}

\section{REQUESTS FOR FRACTURING FLUIDS}

Fracturing fluids must meet a number of requirements simultaneously. [3]

1. Fluids must be compatible with the formation material and formation fluids;

2. Fracturing fluids able to suspending proppants and transporting them deep to the fracture;

3. Can develop the necessary fracture width to accept proppants or to allow deep acid penetration;

4. Low friction pressure down the tubing;

5. Must be an efficient fluid and easily to remove from the formation;

6. Must be stable so that it will retain its viscosity;

7. Stable under treating temperatures in the fracture;

8. The fracturing fluid should be cost-effective.

\section{WATER-BASED FRACTURING FLUIDS}

Water-based fracturing fluids are used in the majority of hydraulic fracturing treatments nowadays. [7] These fracturing fluids have many advantages. Water is cheaper than other types of fracturing fluids. It does using water-based fluids very economical. Water-based fluids can increase hydrostatic head compared with oil, gases and methanol. Water is incombustible and can't be a fire hazard. This type of fluid is easily viscosified, controlled and readily available. The main advantage of using is ease of mixing and ability to recover and reuse the water. The disadvantage is the low viscosity which results in a narrow fracture width. 
Water is inexpensive and widely available fluid in most areas of the world, but not all water could be used for fracturing treatments. Rheology properties can be adjusted as desired very easily adjusted polymer loading and additive loading even during the job if required either in stages or continuously. [8]

\section{OIL-BASED FRACTURING FLUIDS}

Nowadays we can observe an evolution of technology of oil-base fracturing fluids. The technology of using this fluids evolved from solid-carboxylated associative polymers to aluminum-carboxylated associative polymers to aluminum-phosphate associative polymers, [8] and then to iron-phosphate ester technology. The aluminum phosphate ester gels have been improved to gel move crude oils and to enhance temperature stability. The earliest viscosified oils were napalm-type fluids.

Oil-base fluids are operationally difficult to handle and expensive, but these fluids are less damaging to a hydrocarbon-bearing formation than water-base fluids. The main advantage of fracturing treatments with oil-base fluids compared with water-based fluids that some formations can to imbibe large quantities of water, while others are water sensitive and will swell if water is introduced. Thus, oil-base fluids are now used only in formations that are known to be extremely water-sensitive. When using these fluids there are greater concerns regarding personnel safety and environmental impact, as compared to most water-fluids. Gelling problems can occur when using high viscosity crude oils or crude oils which contain a lot of naturally occurring surfactants.

In most cases, the pumping friction of oil-bases fluids is higher than a delayed, crosslinked water-based fluid system. Pumping pressure are also higher because of a lack of hydrostatic head of the hydrocarbon compared with water.[10] In particular, the preparation and quality control of gelling crude oil require much more care than those of water-based fluids.

\section{ACID FLUIDS}

Acid fluids used for low-permeability and acid-soluble rocks. It is formations such as limestone $(\mathrm{CaCO} 3)$ or dolomites $(\mathrm{CaCO} 3 \times \mathrm{MgCO} 3)$. These materials react easily with hydrochloric acid to form chlorides and carbon dioxide. Also acids are used in carbonate formations, acid fracturing in sandstone formations has been not a common practice due to the low rock solubility of mud acid. The best choose for acid treatments is reservoir with temperature less than $200^{\circ} \mathrm{F}$ and the maximum effective stress on the fracture less than 5,000 psi.

Acid fracturing has the advantage that no problem with proppant cleanout will appear. In particular, acids may be mixed with a gelling agent and encapsulated with oils and polymers. 
Acid-fracture fluids with propping agents are not recommended. If a propping agent is used with acid, the fines plug up the propping agent, resulting in very low fracture conductivity. Generating hydrofluoric acid in situ makes it possible to perform acid fracturing of sandstone formations with the assistance of partial monolayer's of effectively placed propping agents and to create enlarged propped fractures. [11]

Acid fracturing is a well stimulation process in which acid is injected into a formation at a pressure sufficient to fracture the formation or to open existing natural fractures. As the acid flows along the fracture, portions of the fracture face are dissolved. Because flowing acid tends to etch in a nonuniform manner, conductive channels are created that usually remain when the fracture closes. The effective length of the fracture is determined by the etched length, which depends on the volume of acid used, its reaction rate and the acid fluid loss from the fracture into the formation. The effectiveness of the acid fracturing treatment is determined largely by the length of the etched fracture. Practically, acid fracturing is less complicated because no propping agent is employed. Also, the danger of proppant screen out and the problems of proppant flowback and cleanout from the wellbore after the treatment are eliminated. The major barrier to effective fracture penetration by acid appears to be excessive fluid loss. In addition, acid leakoff is extremely nonuniform and results in wormholes and the enlargement of natural fractures. This greatly increases the effective area from which leakoff occurs and makes fluid-loss control difficult.

\section{FOAMS AND EMULSIONS}

Emulsion fracturing fluids have been used for many years. They have extremely high friction pressure resulting from their high inhere viscosity and lack of friction reduction. Water emulsion fracturing fluids were introduced in the mid-1970. These fracturing fluids yielding higher friction pressure than comparable water-based gels but it was indeed a breakthrough in our industry and continue to be used widely as a very cost-effective, functional fracturing system. The cost-effectiveness of an oil emulsion implies that the load oil can be produced back and sold. The use of oil-in-water emulsion has decreased recently with the increased cost of crude oil. The emulsion is broken in the formation when the surfactant that created the emulsion is absorbed into the formation.

Foam was not widely used as a fracturing fluid until the mid-1970. Foam fracturing fluids are constructing simply a gas-in-liquid emulsion. When liquid and gas are mixed, gas bubbles are created by turbulence. The gas bubbles provide high viscosity and excellent proppant-transport capabilities. The foam which created by bubbles emulsified in the liquid will break out slowly with time. Advantage is inherent energy in the gas and that minimizing the amount of fluid placed on the formation and improving recovery of fracturing fluid. In preparing foam typically uses $65 \%$ to $80 \%$ less water than in convention treatments, simply promote cleanup in low-pressure formation. Disadvantages much more care must be taken in running 
a foam fracturing treatments from a mechanical point of view. It is very difficult to get high sand concentration in foam fracturing.

Generally, any fluid that has two phases of and viscosity increase because of presence of the second phase can be considered a foam or emulsion. The typical foams or emulsions used in the industry are limited to about 70 to 80 quality to minimize frictional effects due to the high viscosity. The high viscosity of the foams help the fluids has good fluid less control. One of the potential problems using foams is that the recovered fluid can come back as foam, which might be a nuisance to surface equipment.

\section{ENERGIZED FLUID}

Fracturing fluid is often energized either with $\mathrm{N}_{2}$ or $\mathrm{CO}_{2}$ to minimize the amount of liquids introduced into the formation and to enhance recovery of fluids. In the industry it is usually to use 25 to 30 volume percent of energizing medium in fluids. Energized fluids are of particular importance of fracturing under - pressured gas wells. Using $\mathrm{N}_{2}$ or $\mathrm{CO}_{2}$ for energized fluid has a lot of different. In most places, $\mathrm{N}_{2}$ is easily available at lower cost than $\mathrm{CO}_{2}$. Fluids energized with $\mathrm{N}_{2}$ are recovered as soon as possible after pumping ceases. On the other hand, $\mathrm{CO}_{2}$ under pumping conditions is actually a liquid or a supercritical fluid.

The advantages of energizing fracturing fluids are quite obvious, particularly for a formation with low bottomhole pressure. The type of gas used for energizing a fracturing fluid should be considered carefully. The obvious advantages and disadvantages to using $\mathrm{CO}_{2}$ and $\mathrm{N}_{2}$ should be weighed and the relative cost effectiveness compared before their use.

\section{EFFECT OF ROCK MECHANICAL PROPERTIES ON FRACTURING FLUID SELECTION}

Fluid selection for hydraulic fracturing is based on laboratory data and tests. Hydraulic fracturing treatments depends on a lot of different factors, such as type of formation, permeability, formation fluids, closure stress, formation rock mechanical properties etc. The properties of different deposits using testing and their influence on hydraulic fracture network creation. The rock mechanical properties are not enough to forecast the fracture geometry. It is guided by the proper selection of stimulation fluid and stimulation design. Compare the selection of fracturing fluid changes when moving from a ductile to a brittle formation (Fig. 1).

Slick water treatment is usually occur with pumping large volumes of fluid using high pump rates and low proppant concentrations to create a complex of fractures. Young's modulus and low Poisson's ratio are some of the most important parameters for rock mechanics, which can determine the fracture geometry, fracture confinement, and ease of fracturing. High pressures also elastically deform the rock away from the fracture face. This deformation will depend on the pressure above the fracture pressure and Young's modulus of the rock. 


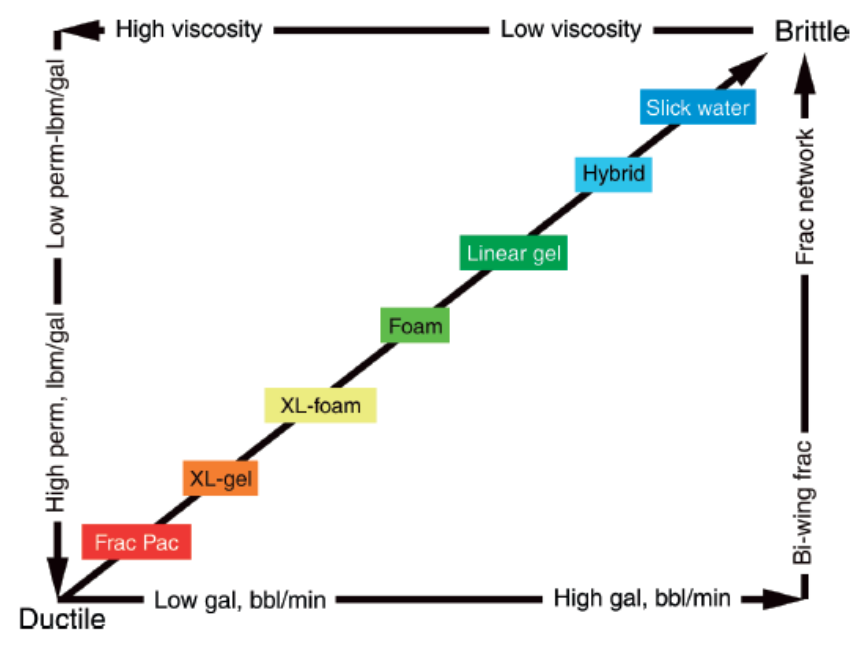

Fig. 1.Relationship between fluid type, formation permeability, and formation rock mechanical properties. [4]

The Poisson's ratio, $v$, is a measure of how much a material will deform in a direction perpendicular to the direction of the applied force, parallel to the plane on which stress induced by the strain in acting. The Poisson's ratio is defined by

$$
v=-\frac{\varepsilon_{y}}{\varepsilon_{x}}
$$

Young's modulus, E, is defines as the ratio of stress over strain

$$
E=-\frac{\sigma}{\varepsilon}
$$

A higher Young's modulus is associated with rock strength that has more fracture confinement. A rock fails under tensile crack. A higher Poisson's ratio suggests more tensile strength and plastic behavior. Fragility caused by a high Young's modulus and low Poisson's ratio creates a larger number of openings, and less proppant concentration is required to hold the conductive channels open.

Usually shale formations are negatively charged. It means that the additives selection must be compatible with the formation. Slickwater solutions are usually best served with a negatively charged friction reducer.

\section{APPLICATION OF HYDRAULIC FRACTURING FLUIDS IN EUROPE}

Nowadays in Europe the compositional data of fracturing fluids are only available for one shale gas fracturing operation in the UK (Cuadrilla), from Poland (BNK) and for 
a number of fracturing operations in Germany (ExxonMobil). The relative magnitude of treatments materials and cost of treatments performed in the United States are estimated as follows: 45 percent for pumping, 25 percent for proppants, 20 percent for fracturing chemicals and 10 percent for acid.

Example of potential additives and their amounts is shown in Fig. 2. [13] Specific fluid compositions for different deposits may differ significantly Fig. 3.

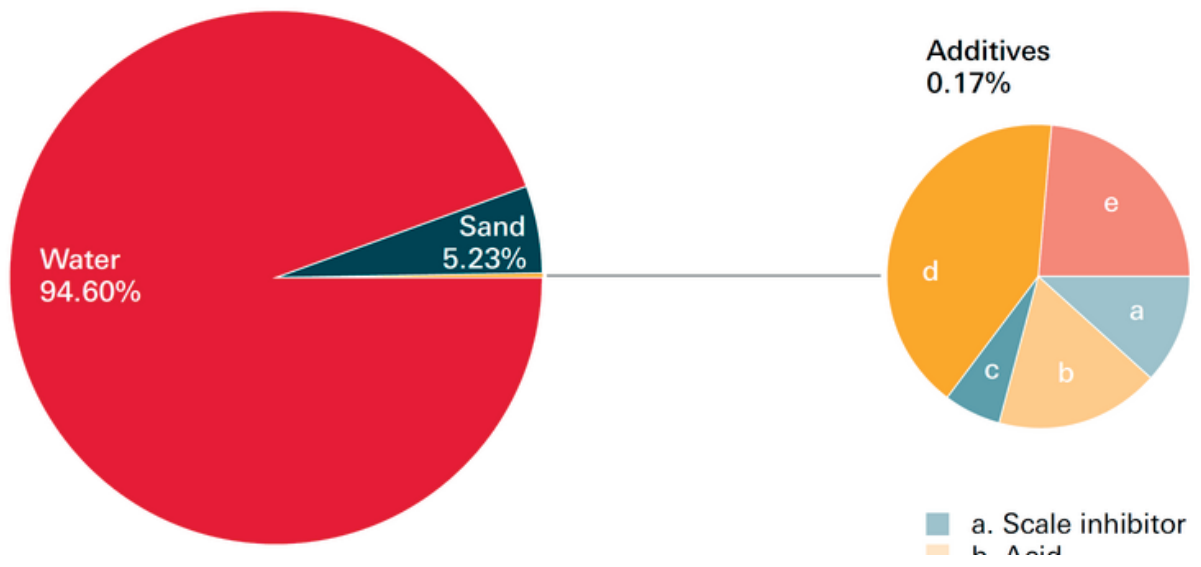

Fig. 2. Example of fracturing fluid composition for shale fracturing.
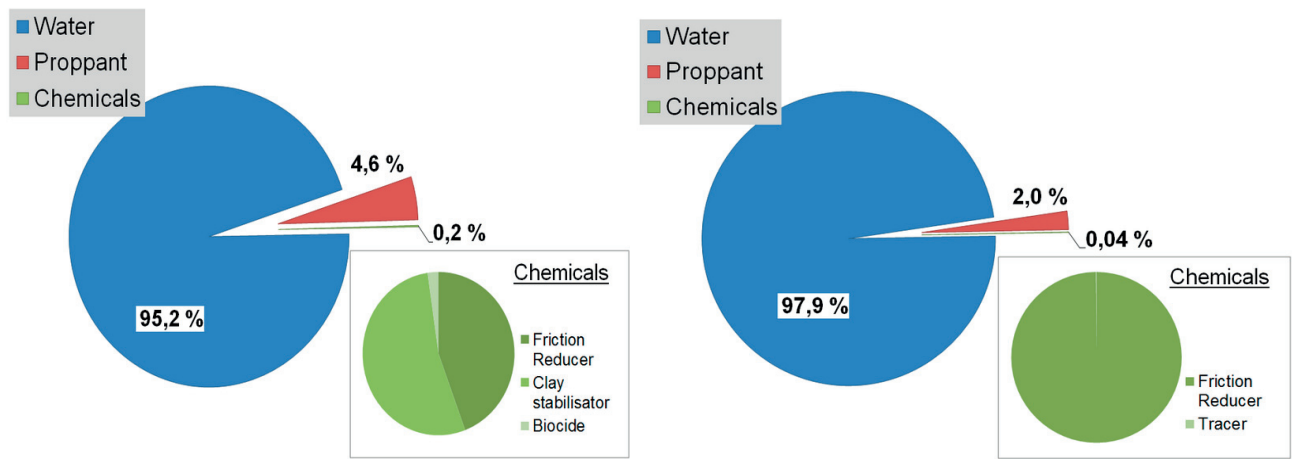

Fig. 3. Fracturing fluid compositions for shale fracturing. Left: ExxonMobil Germany, fluid used in 2008; Right: Cuadrilla, UK, fluid used in 2011

As part of New York State's Draft Supplemental Generic Environmental Impact Statement (SGEIS) related to Horizontal Drilling and High-Volume Hydraulic Fracturing in the Marcellus Shale, the Department of Environmental Conservation compiled a list of chemicals and additives used during hydraulic fracturing. The Table 3 below provides examples of various types of hydraulic fracturing additives proposed for use in New York or in another state of USA. [13] 
Table 3

Examples of various types of hydraulic fracturing additives.

\begin{tabular}{|c|c|c|}
\hline Additive type & Description & Examples \\
\hline Proppant & $\begin{array}{l}\text { Proppant open fractures and allows gas / fluids } \\
\text { to flow more freely to the well bore }\end{array}$ & $\begin{array}{l}\text { Sand(Sintered bauxite; } \\
\text { zirconium oxide; ceramic beads) }\end{array}$ \\
\hline Acid & $\begin{array}{l}\text { Cleans up perforation intervals of cement and } \\
\text { drilling mud prior to fracturing fluid injection, } \\
\text { and provides accessible path to formation }\end{array}$ & $\begin{array}{l}\text { Hydrochloric acid }(\mathrm{HCl}, 3 \% \text { to } \\
28 \% \text { ) or muriatic acid }\end{array}$ \\
\hline Breaker & $\begin{array}{l}\text { Reduces the viscosity of the fluid in order to } \\
\text { release proppant into fractures and enhance the } \\
\text { recovery of the fracturing fluid }\end{array}$ & Peroxydisulfates \\
\hline $\begin{array}{l}\text { Bactericide/ } \\
\text { Biocide }\end{array}$ & $\begin{array}{l}\text { Inhibits growth of organisms that could produce } \\
\text { gases (particularly hydrogen sulfide) that could } \\
\text { contaminate methane gas. Also prevents the } \\
\text { growth of bacteria which can reduce the ability } \\
\text { of the fluid to carry proppant into the fractures }\end{array}$ & $\begin{array}{l}\text { Gluteraldehyde;2-Bromo-2- } \\
\text { nitro-1,2-propanediol }\end{array}$ \\
\hline $\begin{array}{l}\text { Buffer/pH } \\
\text { Adjusting Agent }\end{array}$ & $\begin{array}{l}\text { Adjusts and controls the } \mathrm{pH} \text { of the fluid in order } \\
\text { to maximize the effectiveness of other additives } \\
\text { such as crosslinkers. }\end{array}$ & $\begin{array}{l}\text { Sodium or potassium carbonate; } \\
\text { acetic acid }\end{array}$ \\
\hline $\begin{array}{l}\text { Clay Stabilizer/ } \\
\text { Control }\end{array}$ & $\begin{array}{l}\text { Prevents swelling and migration of formation } \\
\text { clays which could block pore spaces thereby } \\
\text { reducing permeability. }\end{array}$ & $\begin{array}{l}\text { Salts(e.g.,tetramethyl } \\
\text { ammonium chloride) Potassium } \\
\text { chloride }\end{array}$ \\
\hline $\begin{array}{l}\text { Corrosion } \\
\text { Inhibitor }\end{array}$ & $\begin{array}{l}\text { Reduces rust formation on steel tubing, well } \\
\text { casings, tools, and tanks (used only in fracturing } \\
\text { fluids that contain acid }\end{array}$ & $\begin{array}{l}\text { Methanol; ammonium bisulfate } \\
\text { for Oxygen Scavengers }\end{array}$ \\
\hline Crosslinker & $\begin{array}{l}\text { The fluid viscosity is increased using phosphate } \\
\text { esters combined with metals. The metals are } \\
\text { referred to as crosslinking agents. The increased } \\
\text { fracturing fluid viscosity allows the fluid to } \\
\text { carry more proppant into the fractures. }\end{array}$ & $\begin{array}{l}\text { Potassium hydroxide; borate } \\
\text { salts }\end{array}$ \\
\hline Friction Reducer & $\begin{array}{l}\text { Allows fracture fluids to be injected at optimum } \\
\text { rates and pressures by minimizing friction. }\end{array}$ & $\begin{array}{l}\text { Sodium acrylate-acrylamide } \\
\text { copolymer; polyacrylamide } \\
\text { (PAM); petroleum distillates }\end{array}$ \\
\hline Gelling Agent & $\begin{array}{l}\text { Increases fracturing fluid viscosity, allowing the } \\
\text { fluid to carry more proppant into the fractures. }\end{array}$ & Guar gum; petroleum distillate \\
\hline Iron Control & $\begin{array}{l}\text { Prevents the precipitation of carbonates and } \\
\text { sulfates (calcium carbonate, calcium sulfate, } \\
\text { barium sulfate) which could plug off the } \\
\text { formation. }\end{array}$ & $\begin{array}{l}\text { Ammonium chloride; ethylene } \\
\text { glycol; polyacrylate }\end{array}$ \\
\hline Solvent & $\begin{array}{l}\text { Additive which is soluble in oil, water \& acid- } \\
\text { based treatment fluids which is used to control } \\
\text { the wettability of contact surfaces or to prevent } \\
\text { or break emulsions }\end{array}$ & Various aromatic hydrocarbons \\
\hline Surfactant & $\begin{array}{l}\text { Reduces fracturing fluid surface tension thereby } \\
\text { aiding fluid recovery }\end{array}$ & $\begin{array}{l}\text { Methanol;isopropanol; } \\
\text { ethoxylated alcohol }\end{array}$ \\
\hline
\end{tabular}




\section{CONCLUSION}

Hydraulic fracturing is a necessary technique to improve gas production from unconventional reservoirs. The selection of fracturing fluids is a major component of designing and implementing a hydraulic fracturing treatment. The recipe of the fracturing fluid must be carefully chosen for provide maximum success and continual production over the long term. The choice of stimulation fluid and proppant plays a vital role in creating the shape and distribution of the fracture network. The ideal fracturing fluid should have minimal pressure drop in the pipe during operation, have sufficient viscosity to deliver proppant in fracture. For selecting the fluid very important to choose the main characteristics: availability, viscosity characteristics, safety, ease of mixing and use, compatibility with formation, ability to be cleaned up from the fracture, and cost. However, viscosity properties are the most important properties of fracturing fluids.

Hydraulic fracturing operations vary widely in the types of fracturing fluids used, the volumes of fluid required, and the pump rates at which they are injected. Proppants and chemicals compose a larger share of the total cost of hydraulic fracture treatments a well. Water with a simple sand proppant can be adequate to achieve a desired fracture at some sites. In some cases, water must be thickened to achieve higher proppant transport capabilities. Thickening can be achieved by using linear or crosslinked gelling agents. Crosslinking is the most cost-effective way of increasing the viscosity of the fluid. Crosslinkers are costly additives compared to simple linear gels, but a fluid's fracturing efficiency can be greatly improved using cross-linkers. Usually, a gelled water or crosslinked gel fluid is used as the pad fluid to fill the wellbore and break down the formation. Foams are especially useful in watersensitive or low pressure reservoirs. These fracturing fluids can be used to considerably reduce the amount of injected fluid required. The reduced water volume requirement translates into a space and cost savings at the treatment site because fewer water tanks are needed. Foam fracturing fluids also promote rapid flowback and reduced volumes of flowback water requiring disposal. One of the easiest methods of creating viscosity to control leak-off and suspend the proppants is to add guar gum. The guar derivatives are generally safe to dispose into the environment, crosslinker may not be, and this can restrict their application. If there are concerns about the effect of using a water-based fluid in the reservoir, oil-based fracturing fluids are used. Such concerns are prevalent in low-permeability gas wells and sensitive formations. In general, acid fracturing is best applied in shallow, low-temperature carbonate reservoirs. The best candidates are shallow, in which the reservoir temperature is less than $200^{\circ} \mathrm{F}$ and the maximum effective stress on the fracture will be less than 5,000 psi.

Selection of the fracture fluid is a critical decision for fracture treatment. Fracture fluid's selection is based on factors such as determination if the reservoir is water sensitive, reservoir temperature and pressure, the expected value of fracture half-length.

\section{REFERENCES}

[1] M. Economides, R. Oligney, P.Valko, United Fracturing Design, 2000, Orsa Press, Texas

[2] J.K.Fink, Hydraulic Fracturing Chemicals and Fluids Technology, 2013, Elsevier inc,USA 
[3] Michael J.Economides, Kenneth G. Note, Reservoir Stimulation Third Edition, 2000, Schlumberger, Texas.

[4] P. Das, M. Achalpurkar, Impact of Rock Mechanics and Formation Softening Analysis in Shale Fracturing Fluid Design, 2013, SPE 167336.

[5] A.Reinicke, E.Rybacki, S.Stanchits, E.Huenges, G.Dresen, Hydraulic fracturing stimulation technique sand formation damage mechanisms - Implications from laboratory testing of tight sandstone-proppant systems, 2010, Helmholtz Centre Potsdam, GFZ German Research Centre for Geosciences, Telegrafenberg, 14473 Potsdam, Germany

[6] G. Zimmermann , G. Blocher, A. Reinicke, W. Brandt, Rock specific hydraulic fracturing and matrix acidizing to enhance a geothermal system - Concepts and field results, 2010, Helmholtz Centre Potsdam, GFZ German Research Centre for Geosciences, Telegrafenberg, D14473 Potsdam, Germany

[7] John L. Gidley, Stephen A. Holditch, Date E. Nierode, Ralph W. Veatch, Resent Advances in Hydraulic Fracturing, 1989, SPE, Richardson, Texas.

[8] Michael J. Economides, Tony Martin, Modern Fracturing Enhancing Natural Gas Production, 2007, ET Publishing, Houston, Texas.

[9] C. Montgomery, Brisbane, Fracturing Fluid May Components, 2013, International Conference for Effective and Sustainable Hydraulic Fracturing, Australia.

[10] Phillip C. Harris, Fracturing-Fluid Additives, Journal of Petroleum Technology, October 1988,SPE, Halliburton Services.

[11] C. E. Cooke, Jr., Effect of Fracturing Fluids on Fracture Conductivity, JOURNAL OF PETROLEUM TECHNOLOGY, SPE-AIME, Exxon Production Research Co.

[12] A. Gaurav, E.K. Dao, K.K. Mohanty, Evaluation of ultra-light-weight proppants for shale fracturing, Petroleum and Geosystems Engineering, The University of Texas at Austin, 1 University Station C0300, Austin, TX 78712, USA.

[13] Shale gas extraction in the UK: a review of hydraulic fracturing, June 2012 DES2597, The Royal Society and The Royal Academy of Engineering. 